UDK 528.92

\title{
SKENUOTŲ ŽEMĖLAPIŲ VAIZDO KOKYBE்S VERTINIMAS IR GERINIMO BŪDAI Adobe PhotoShop PROGRAMA
}

\author{
Artūras Bautrẻnas ${ }^{1}$, Jana Konstantinova ${ }^{2}$, Marijus Pileckas ${ }^{2}$ \\ ${ }^{I}$ Vilniaus universitetas, M. K. Čiurlionio g. 21/27, LT-03101 Vilnius, Lietuva, \\ ${ }^{2}$ Geologijos ir geografijos institutas, T. Ševčenkos g. 13, LT-03223 Vilnius, Lietuva, \\ el.paštas: arturas.bautrenas@gf.vu.lt, jana@geo.lt, marijus@geo.lt
}

Iteikta 20050210, priimta 20051214

\begin{abstract}
Santrauka. Nagrinėjamas kartografinių kūrinių vertimo skaitmeniniais skenuojant, gautų rastrinių žemėlapiu kokybės vertinimo ir gerinimo bei įvairių defektų šalinimo, taikant Adobe PhotoShop programą, procesas, pateikiamas rastrinio žemèlapio rengimo numatytai paskirčiai algoritmas.
\end{abstract}

Prasminiai žodžiai: skenavimas, rastrinio vaizdo kokybè.

\section{Ivadas}

Dabartinejje informacinèje erdvèje vis labiau isigali skaitmeniniai duomenys. Ši tendencija neaplenkè ir kartografinių kūrinių. Šiuolaikinès technologijos leidžia gauti ir koreguoti analoginių žemèlapių skaitmenini vaizdą. Populiariausias ir paprasčiausias būdas analogini žemėlapi paversti skaitmeniniu - ji skenuoti. Gautiems rastriniams vaizdams koreguoti naudojamos ivairios grafinès programos.

Nors geografai Lietuvoje jau plačiai naudoja skaitmeninius rastrinius vaizdus, dauguma neturi pakankamai žinių, kaip tinkamai nuskenuoti reikiamą žemèlapi ir gautą skaitmenini vaizdą paruošti numatytiems tikslams. Spragai užpildyti buvo atliktas tyrimas, kurio rezultatai pateikiami šiame straipsnyje.

\section{Metodika}

Rastriniams vaizdams apdoroti tinkamiausia dabar naudojama grafinè kompiuterinè programa yra Adobe PhotoShop [1]. Ši programa priskiriama prie profesionalių grafinès programinès irangos produktų, nes joje yra visos priemonès, reikalingos rastriniams vaizdams apdoroti. Šia programa galima keisti ne tik vaizdo kokybę, bet ir geometrinius parametrus, o tai labai svarbu rengiant skaitmeninius žemėlapius. Todèl tyrimui buvo pasirinkta būtent ši grafinė programa.

Žemèlapių vaizdo kokybei tirti buvo parinkta ịvairiu pavyzdžių. Iš viso iš ivairių šaltinių (mokyklinių ir nacionalinių atlasų, senų žemėlapių rinkinių, pavienių žemėlapiu) buvo nuskenuota 52 ívairios paskirties (mokykliniai, turistiniai, reklaminiai, moksliniai ir kt.) žemėlapiai.

Skenavimo ir gauto skaitmeninio vaizdo kokybès vertinimo bei koregavimo procesui optimizuoti buvo atlikti įvairūs specialūs tyrimai:
- $\quad$ siekiant parinkti optimalią skyrą, žemèlapiai buvo skenuojami kelis kartus, gautieji ivairios skyros vaizdai palyginti tarpusavyje;

- programos Adobe PhotoShop filtru panaudojimo skaitmeninių žemèlapių kokybei gerinti galimybès nustatytos žemėlapius paveikus šios programos filtrais;

- skaitmeninio žemėlapio rengimo algoritmui sukurti buvo nuskenuotas ir parengtas spaudai senas labai pažeistas žemèlapis.

Taip pat straipsnio autoriai ivertino ir apibendrino kitų tyrèjų darbus [2, 3] šiuo klausimu bei savo patirti, igytą žemėlapius paverčiant skaitmeniniais bei rengiant gautus rastrinius vaizdus vektorizuoti bei publikuoti.

\section{Analoginio žemėlapio skenavimas}

Skenavimas dabar labiausiai paplitęs būdas gauti rastrini skaitmenini vaizdą. Skeneriu yra ivvairių tipų, jie skiriasi galimybėmis [4]. Plačiausiai naudojami planšetiniai skeneriai.

Skaitmeninis fotografavimas šiame straipsnyje nenagrinejamas, nes fotografuojant paprastu skaitmeniniu fotoaparatu esti dideli geometriniai bei spalvų nuokrypiai, tad gautasis vaizdas tinka nebent peržiūrai.

Prieš skenuojant labai svarbu pasirinkti tinkamiausią originalą (jei yra iš ko rinktis) bei ivertinti prieinamos techninès (skenerio) ir programinès (skenavimo ir vaizdo apdorojimo programu) irangos galimybes [5].

Skenavimo procesą galima skaidyti $\mathfrak{i}$ tris etapus:

- originalo paruošimas skenuoti;

- skenavimas;

- nuskenuoto vaizdo išsaugojimas.

Originalo ruošimas skenuoti. Skenuojamas originalas ne visada būna geros kokybès. Gali pasitaikyti sulamdytu, suplèšytų ir apipieštų žemėlapių. Tokius trūkumus kiek ìmanoma būtina pašalinti dar prieš 
skenuojant. Nuskenavus žemėlapi liks mažiau defektų ir sumažès skenuoto vaizdo koregavimo darbų [6].

Skenavimo parametrų parinkimas. Prieš skenuojant originalą, skenavimo programoje labai svarbu nustatyti skenavimo parametrus, kurie turi esminę itaką skenuoto vaizdo kokybei. Skenavimo parametru parinkimas labiausiai priklauso nuo tolesnès skenuoto vaizdo paskirties.

Vienas iš svarbiausių parametrų yra skenavimo skyra, turinti lemiamą itaką skenuoto vaizdo kokybei. Skyra taip pat yra lemiamas ir grafinès bylos dydžio veiksnys (kuo didesnè skenavimo skyra, tuo daugiau atminties užims skenuotas vaizdas). Šiuolaikiniai skeneriai leidžia skenuoti iki 12000 dpi (tašku colyje) skyra. Tačiau netikslinga visus žemėlapius skenuoti didele skyra, nes tuomet gaunamos labai didelés bylos. Parenkant optimalią skyrą lemia tolesnè skenuoto vaizdo paskirtis, t. y. kam bus naudojamas skenuotas vaizdas ir kokios kokybės reikia. Rekomenduojama skyra [3]:

- 72 dpi - jeigu vaizdai bus dedami iz interneta;

- 100-150 dpi - laikraščiams spausdinti arba žemos kokybès rašaliniams spausdintuvams;

- 300-350 dpi - poligrafinei spaudai ir geros kokybès spausdintuvams. Tai pagrindinè skenavimo skyra, jei vaizdą vèliau numatoma spausdinti.

Norint isitikinti, kokia skyra geriau skenuoti žemėlapius, buvo atliktas eksperimentas: tas pats žemėlapis buvo nuskenuotas ịvairia skyra (1 pav.). Paaiškejjo, kad tarp 300 ir 600 dpi skyra skenuotu žemėlapių vaizdo kokybès vizualių skirtumų beveik nematyti. Taigi galime teigti, kad jei vaizdas bus naudojamas spausdinimui, pakanka skenuoti 300-350 dpi skyra. O jei vaizdas toliau bus naudojamas vektorizavimui, užtenka nustatyti 150-200 dpi skyrą.

Atsižvelgiant i skenuojamo žemèlapio spalvines charakteristikas ir numatomą skenuoto vaizdo paskirti reikia nustatyti spalvini režimą. Nuo to taip pat priklausys bylos dydis - kuo daugiau spalvu naudosime, tuo didesnę bylą gausime. Yra trys pasirinkimo galimybès:

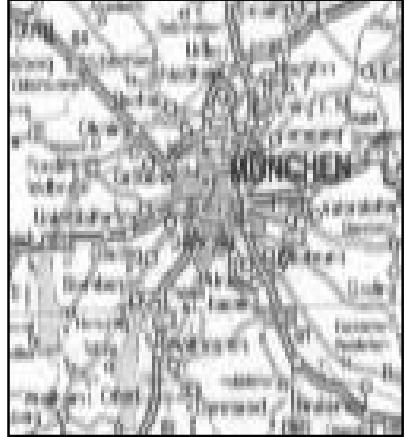

75 dpi

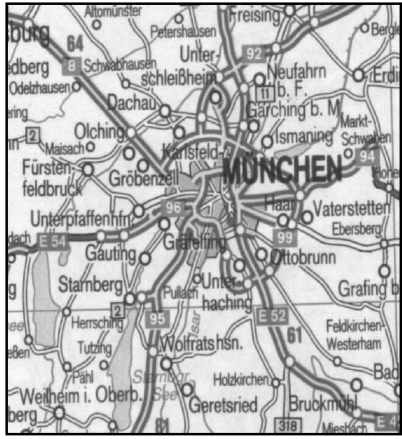

$350 \mathrm{dpi}$
1 pav. Žemèlapio fragmentas, skenuotas skirtinga skyra Fig 1. Map scanned with a different resolution
1. Taikant linijini (Linear) režimą naudojamos tik dvi spalvos - absoliuti balta ir absoliuti juoda. Šiuo režimu patartina skenuoti vienspalves schemas bei žemėlapius, kuriuose informacija vaizduojama linijomis ir užrašais.

2. Taikant pilkos spalvos gradacijos (Grayscale) režimą naudojami 255 pilkos spalvos atspalviai. Šis režimas geriausiai tinka skenuoti žemėlapius, kuriuose informacija vaizduojama viena pagrindine spalva arba jos atspalviais. Skenuojant spalvotą žemėlapi, ši režimą galima rinktis tuo atveju, jei reikia gauti nespalvota vaizdą (pvz., jei skenuotas vaizdas bus naudojamas nespalvotai spaudai), arba skenuotame vaizde nebūtina išlaikyti originalo spalvas (pavyzdžiui, jei skenuotas vaizdas bus naudojamas vektorizavimui).

3. $R G B$ režimu žemėlapiai skenuojami spalvotai. Jei žemėlapis yra spalvotas, ir spalvinè informacija svarbi, būtina rinktis ši režimą.

Poligrafinio muaro pašalinimo galimybė. Skenuojant žemèlapius dažnai susiduriama su poligrafiniu muaru - spalvos esti ne vientisos, o susideda iš linijų arba taškų (2 pav.).

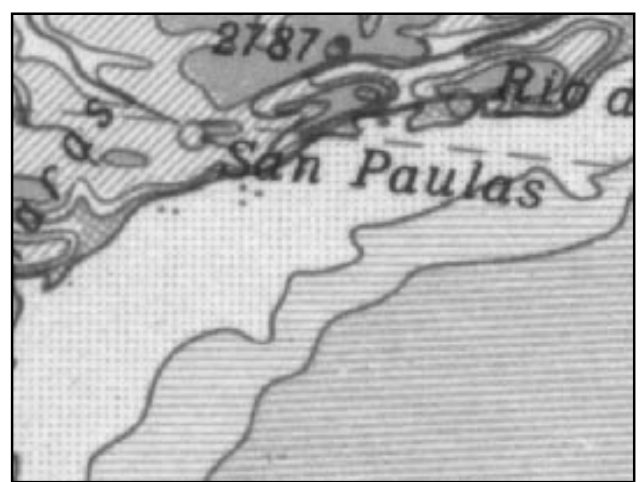

2 pav. Poligrafinis muaras

Fig 2. Polygraphical moire

Kai kurios skenavimo programos leidžia pašalinti muara jau skenuojant. Naudojama komanda Descreen, kuri atpažista ir pašalina poligrafini muarą. Komandos parametruose reikia nustatyti skenuojamo originalo tipa (laikraštis, žurnalas, aukštos poligrafinès kokybės originalas, kt.) ir skenuoti didesne skyra, nes ši komanda geriau veikia didesnès skyros vaizduose. Deja, tokias galimybes turinčios skenavimo programos yra gana brangios ir eiliniam vartotojui ne visada prieinamos.

Skaitmeninio vaizdo išsaugojimas. Skenuotam vaizdui išsaugoti labai svarbu nurodyti tinkamą formatą. Bylos išsaugojimo formato parinkimą lemia numatoma skenuoto vaizdo paskirtis bei grafinès programos, kuria toliau bus apdorojamas vaizdas, ypatybès (kokius rastriniu duomenu formatus turi naudojama grafinè programa) [7]. Jeigu skenuotą vaizdą numatoma spausdinti, geriausia ji saugoti TIFF formatu, kuris dažniausiai naudojamas leidyboje. Formatas TIFF (Tagged Image File Format) yra visose grafinèse programose, ivairiose operacinèse platformose, šio formato vaizdai geros kokybès, nes naudojamas $L Z W$ suspaudimo algoritmas neleidžia prarasti informacijos. 
Tačiau TIFF formatu išsaugotos bylos yra gana didelès. Todèl, jei skenuotas vaizdas nebūtinai turi būti aukštos kokybès (pvz., jei skenuotas vaizdas bus naudojamas vektorizavimui), ji galima išsaugoti kitais formatais, kurie duomenis glaudina efektyviau, tačiau prarandant dali informacijos, pvz. JPG (JPEG) formatu. Jeigu skenuotas vaizdas bus dedamas i interneta, ji rekomenduojama išsaugoti GIF formatu.

\section{Galimi skaitmeninio skenuoto vaizdo defektai, jų vertinimas bei šalinimo galimybès}

Skaitmeniniame skenuoto žemėlapio vaizde dèl ivvairių priežasčių gali atsirasti defektų. Pagrindiniai galimi skaitmeninio vaizdo defektai:

- geometrinès deformacijos;

- netinkamas vaizdo ryškumas;

- fiziniai originalo pažeidimai (ịtrūkimai, ỉbrèžimai, perlenkimai ir t. t.) perkeliami i skaitmenini vaizdą;

- muaras

- Niutono žiedai.

Daugeliu atvejǔ šiuos skaitmeninio vaizdo defektus galima panaikinti Adobe PhotoShop programa. Jeigu defektai yra reikšmingi, ir jų pašalinti nepavyksta, žemèlapi reikia skenuoti iš naujo arba ieškoti kito originalo.

\subsection{Geometrinès skaitmeninio vaizdo deformacijos}

Geometrinès deformacijos - tai linijiniai arba kampiniai vaizdo iškraipymai. Dažniausiai jie atsiranda:

- skenuojamą originalą netinkamai orientavus skenavimo elemento atžvilgiu;

- dèl skenerio konstrukcinių trūkumų (skenuojamo originalo pakraštys „užlipa“ ant skenerio krašto ir ,išlinksta“) (3 pav.);

- dèl paties skenuojamo originalo deformacijuc (analoginis žemèlapis ilgainiui, ypač jeigu laikomas prastomis sąlygomis, deformuojasi).

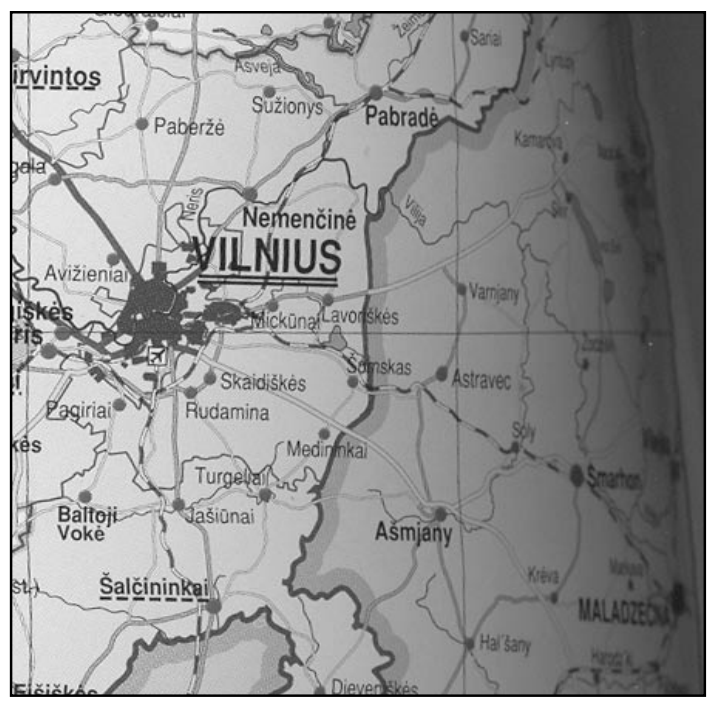

3 pav. Geometrinès deformacijos

Fig 3. Geometric deformations
Geometrinès deformacijos - vienas iš svarbiausių defektų, kurị būtina pašalinti. Perorientuoti skenuotą vaizdą nesunku, antruoju atveju - originalą reikia skenuoti iš naujo [8].

Jeigu geometrinis tikslumas ypač svarbus, galima atlikti originalo ir skenuoto vaizdo matavimus, ieškant linijinių ir kampinių deformacijų. Dažniausiai tai atliekama matuojant atkarpų ilgius ir polinkio kampus tarp pasirinktų taškų originale ir skenuotame vaizde. Taip pat būtina apskaičiuoti teorines atkarpas ir kampus, nes galimos ir paties skenuojamo originalo deformacijos. Pagal gautus matavimo skirtumus galima apskaičiuoti pataisas. Programa Adobe PhotoShop leidžia išmatuoti ir atkurti ilgius ir pločius iki $0,0001 \mathrm{~mm}$ tikslumu, o kampus - iki 0,0001 (0,3”) laipsnio tikslumu; tokio tikslumo dažniausiai pakanka.

\subsection{Netinkamas vaizdo ryškumas}

Palyginti su originalu, skenuotas vaizdas dažniausiai praranda ryškumą. Ryškumo sumažèjimui ịtakos gali turèti:

- skenerio kokybe்;

- neteisingai parinkti skenavimo parametrai, pirmiausia skyra (dažniausiai per maža).

Dèl sumažèjusio ryškumo skenuotas vaizdas tampa tarsi ,išplaukęs“", blogiau skaitomas: dingsta smulkios detalès, nebeįskaitomi ar sunkiai įskaitomi užrašai, sunku nustatyti kontūrų (linijinių objektų, arealu) ribas. Todèl skenuotas vaizdas gali būti nebetinkamas numatytiems tikslams.

Programa Adobe PhotoShop leidžia paryškinti ir visą vaizdą, ir kontūrus. Jei ryškumas vis tiek lieka nepatenkinamas, žemèlapi reikia skenuoti iš naujo didesne skyra.

Vaizdo skyros koregavimas. Naudojant skenuotą vaizdą, gali paaiškèti, kad jo skyra per maža. Norint ištaisyti tokią klaidą, geriausia dar kartą skenuoti originalą didesne skyra. Jeigu to padaryti nebeimanoma, skyrą galima padidinti programa Adobe PhotoShop. Skyra keičiama lange Image-Image Size, eilutèje Resolution nustatant reikiamą reikšmę. Tokia operacija kiek padidina vaizdo ryškumą, tačiau iš esmès jo kokybė nepagerèja, nes papildomi taškai interpoliuojami iš jau esamų. Kartais reikia sumažinti vaizdo skyrą (spaustuvès reikalavimai, elektroniniai leidiniai).

Visą vaizdą ar kontūrus paryškinti rekomenduojama taikant universaluji Unsharp Mask (filtrų grupė Sharpen) [7]. Dažniausiai kokybiškiems vaizdams šio filtro užtenka. Filtras turi tris nustatymo padètis (4 pav):

- Amount - ryškumo lygis. Kuo didesnè reikšmė, tuo labiau paryškinamas vaizdas;

- Radius - kontūrų ryškumas. Kuo mažesnè reikšmè, tuo labiau paryškinami kontūrai;

- Threshold - ryškumo skirtumas. Ši padètis lemia, ar Adobe PhotoShop programa padidins dvieju šalia esančių konkrečiu pikselių kontrastą. 


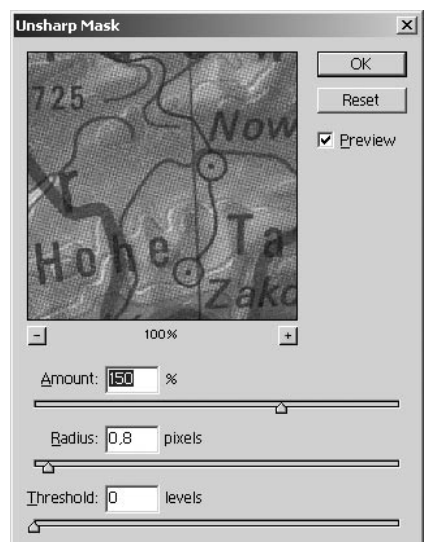

4 pav. Filtro Unsharp Mask režimų nustatymo langas Fig 4. Properties of filter Unsharp Mask

Norint padidinti ryškumą tik kontūrų pakraščiuose, labiausiai tinka specialus filtras Sharpen Edges (filtrų grupe Sharpen). Toks ryškumo didinimas vadinamas pseudoryškumu, nes programa Adobe PhotoShop nekuria trūkstamų pikselių vaizdo ryškumui pagerinti, o tik padidina šalia esančių pikselių kontrastą. Taip pat galima naudoti minètaji filtrą Unsharp Mask.

Objektų kontūrams pastorinti geriausia naudoti filtrą Poster Edges (filtrų grupè Artistic). Filtras paryškina užrašus, linijas bei arealų ribas. Jei taikant ši filtrą kontūrai lieka nepakankamai ryškūs, patartina taikyti filtrą Unsharp Mask, nustatant nulinę parametro Treshold reikšmę.

Kadangi minètieji filtrai didina vaizdo ryškumą, juos galima laikyti ryškinimo filtrais.

\subsection{Fiziniai skenuoto originalo pažeidimai}

Skenuojant i skaitmenini vaizdą perkeliami visi fiziniai originalo trūkumai. Skenavimo programa originalo pažeidimu pašalinti negali, todèl tokie veiksmai yra atliekami taikant grafines programas. Dažniausiai pasitaikantys defektai:

- Perlenkimai, dèmès, pašaliniai užrašai. Šiems trūkumui pašalinti geriausia naudoti iranki Clone Stamp, jis leidžia kopijuoti ir perkelti bet kuri skenuoto vaizdo fragmentą. Irankis turi keletą parametrų, kuriuos keičiant nustatomas „klonuojamo“ fragmento permatomumo (Opacity) bei kraštų ryškumo (Flow) lygis. Didelių plotų spalviniam tonui išlyginti patartina naudoti panašų iranki Healing Brush.

- Smulkūs trukdžiai. Tai nedideli įbrèžimai originale bei trukdžiai, atsiradę dèl netvarkingo skenerio stiklo paviršiaus (stiklo įbrèžimai, dulkès ir t. t.).

Tokius trukdžius geriausia šalinti taikant specialų Dust\&Scratch filtrą (filtru grupe Noise) (5 pav.). Taip pat galima naudoti panašius grupès Blur filtrus Gaussian Blur arba Smart Blur. Keičiant šių filtrų nustatymo parametrus Radius nustatomas šalia esančių pikselių, kurių spalva gali būti suvienodinta, skaičius; (kuo didesnè reikšmè, tuo vaizdas labiau „sulietas“), keičiant parametrus Threshold nustatomas spalvų diapazonas; (kuo didesnè reikšmė, tuo kontrastingesnès spalvos suliejamos). Nors šie filtrai leidžia pašalinti kai kuriuos smulkius trukdžius, turi ir trūkumą - sulieja vaizdą (todèl šiuos filtrus galima vadinti suliejimo filtrais). Skenuotas vaizdas tampa mažiau ryškus, ji gali tekti ryškinti naudojant ryškinimo filtrus. Suliejimo efektui sumažinti, rekomenduojama parametro Threshold reikšmę nustatyti kuo mažesnę, o Radius - reikšmę priklausomai nuo trukdžių dydžio. Panaudojus filtrus, dažnai dalis trukdžių lieka. Jie šalinami naudojant ịankị Clone Stamp.

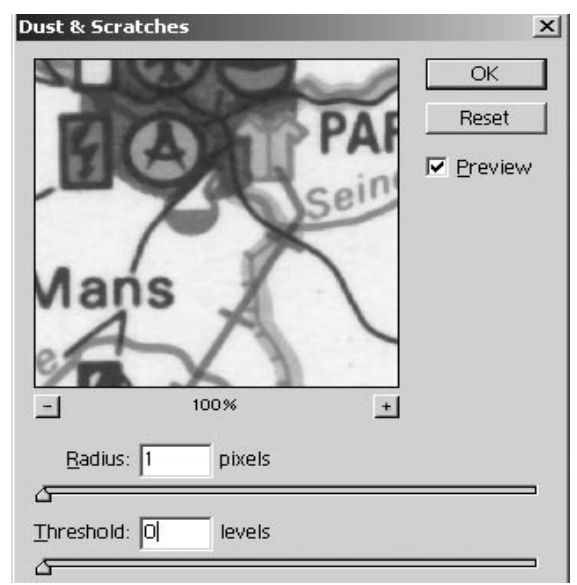

5 pav. Filtro Dust\&Scratch režimų nustatymo langas Fig 5. Properties of filter Dust\&Scratch

- Persišviečiantis vaizdas. Prie fizinių vaizdo pažeidimų galima priskirti toki defektą, kai skenuotame vaizde matoma kita lapo pusè.

Šis defektas dažniausiai pasitaiko skenuojant leidinius, kurių lapai ploni ir/arba popierius yra blogos kokybès. Siekiant išvengti šio defekto reikia skenuoti originalą iš naujo, uždengiant juodu popieriumi. Jei ši trūkumą pastebejjome tik nuskenavę žemėlapi ir iš naujo nuskenuoti neturime galimybès, defektą pašalinti bus sunku. Jei defektas ryškus nedideliame žemèlapio fragmente, ji galima pašalinti naudojant Clone Stamp arba Healing Brush ịrankị.

- Skyles. Kartais pasitaiko, kad skenuojamas žemèlapis suplěšytas ir dalis informacijos dingusi. Ši defektą galima pašalinti naudojant kitus informacijos šaltinius ir kopijavimo iranki Clone, tačiau geriausia surasti ir nuskenuoti sveiką žemėlapi.

\subsection{Muaras}

Šis defektas aktualus tik tuomet, jeigu skenuotas žemèlapis bus spausdinamas. Kaip jau minejjome, muara galima pašalinti skenuojant vaizdą. Jeigu to nepadarėme, muarą galima pašalinti taikant suliejimo filtrus. Geriausia taikyti filtrą Dust\&Scratch. Atlikti tyrimai rodo, kad jo parametro Threshold reikšmę reikia nustatyti 40 ar didesnę. Tačiau kad vaizdas nepataisomai neprarastu ryškumo, muarą reikia šalinti kiekviename spalviniame kanale atskirai. Norint, kad muaras būtų efektyviai pašalintas, ir vaizdas neliktų ,išplaukęs“, rekomenduojama skenuoti didesne skyra (pašalinus muarą, skyrą galima sumažinti). Pašalinus muarą vaizdas vèl paryškinamas, taikant filtrą Unsharp Mask. Sušvelninti muarą galima ir tokiu būdu: žemèlapis skenuojamas daug didesne skyra nei reikia, o tada skyra sumažinama. 


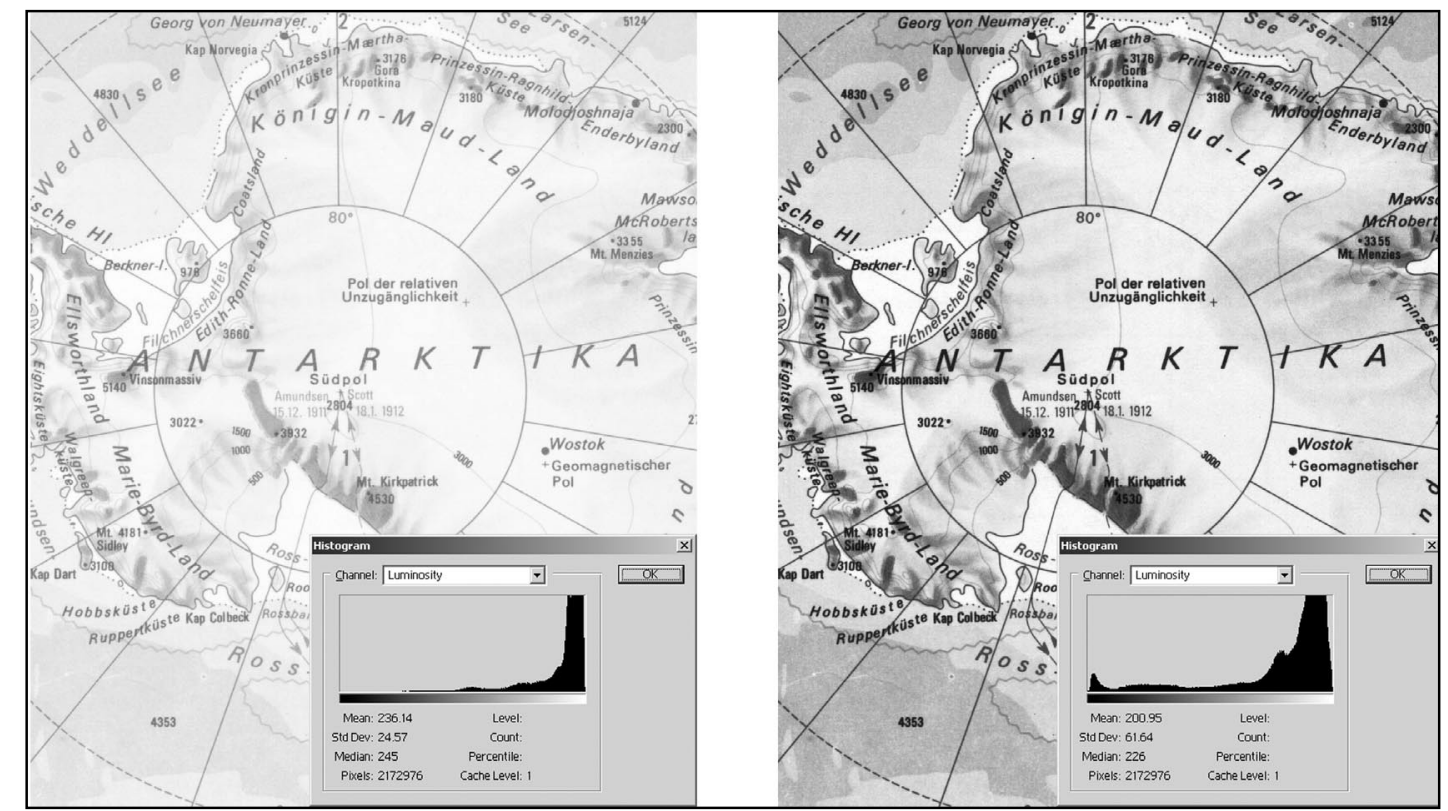

6 pav. Žemèlapio histograma: kairèje - po skenavimo išblukęs vaizdas, dešinėje - vaizdas atlikus spalvų balansavimą Fig 6. Hystogram of a map view: light view after scanning (left) and improved view after correction of colours (right)

\subsection{Niutono žiedai}

Tai rečiausiai pasitaikantis defektas. Jis gali atsirasti todèl, kad skenuojamas originalas nepriglunda prie skenerio darbinio paviršiaus. Defektas dažniausiai pasitaiko skenuojant laminuotus ar ant blizgančio popieriaus atspausdintus žemèlapius.

Toki defektą pašalinti sunku, o jei jis apima sritis, kur didelis objektų tankumas - faktiškai neįmanoma. Geriausiai originalą skenuoti iš naujo, gerai prispaudžiant prie skenerio darbinio paviršiaus. Siekiant išvengti Niutono žiedų efekto, gali būti naudojami ìvairūs aerozoliai ir tepalai. Jais padengiamas skenerio stiklas ir skenuojamasis originalas, taip pašalinamas oro intarpas. Bet tai nèra labai patogios priemonès. Jas panaudojus reikia plauti ir skenerio stiklą, ir patị žemèlapi.

Jeigu Niutono žiedai atsirado vaizdo srityje, kurioje objektų tankumas nèra didelis, defektą galima pašalinti taikant irankị Healing Brush. Taip pat galima apibrěžti vaizdo sriti, kurioje atsirado defektas ir sumažinti ryškumą Blur grupès filtrais. Vaizdas vèl paryškinamas taikant filtrą Unsharp Mask.

\section{Spalvų koregavimas}

Nuskenavus žemėlapi dažnai gaunamas šviesesnis arba tamsesnis vaizdas. Dideli nuokrypiai matomi akivaizdžiai, tačiau dažniausiai skirtumas nèra ryškus. Be to, per ilgą laiką žemėlapis gali būti išblukęs. Todèl, jeigu skenuotas vaizdas bus spausdinamas, gali tekti koreguoti spalvas. Vaizdo spalviniam balansui analizuoti programoje Adobe PhotoShop naudojamos histogramos diagramos, kuriu ordinačiu $(y)$ ašis rodo spalvos intensyvumą, o abscisių $(x)$ ašis - spalvos ryškumą [9]. Histograma gali būti taikoma visam vaizdui arba kiekvienai spalvai atskirai (6 pav.). Histograma dalijama i tris dalis: tamsiaja, vidutinio šviesumo ir šviesiają. Net nematydami skaitmeninio vaizdo, iš histogramos galime ivvertinti vaizdo šviesumą: jei ryškumo vidurkis (Mean) yra pasislinkęs i tamsiają pusę, turime tamsų vaizdą, jei i šviesos pusę - šviesų vaizdą.

Skaitmeninio vaizdo spalvų koregavimą galima atlikti keliais būdais:

- taikant lygiú (Levels) metodą. Šio metodo lange matome skenuoto vaizdo histogramą ir kelias slinkimo juostas, kurias stumdydami galime šviesinti arba tamsinti vaizdą. Tas pačias funkcijas galima taikyti visam vaizdui iš karto arba koreguoti kiekviename spalviniame kanale atskirai;

- taip pat galima taikyti automatinę Levels metodo funkciją AutoLevel. Atlikus tyrimus nustatyta, kad užtenka $30 \%$ automatinio balanso. Automatinio spalvų balansavimo procentas nustatomas meniu Edit pasirinkus komandą Fade (ši komanda tampa aktyvi tik atlikus pirmini automatini spalvų balansavimą komanda AutoLevel).

- kreiviu (Curves) metodas. Šis metodas leidžia balansuoti ir viso vaizdo, ir pavienių kanalu spalvas (7 pav.). Norint pašviesinti tamsų vaizdą, reikia išlenkti kreivę $\mathfrak{i}$ viršu, norint patamsinti - $\mathfrak{i}$ apačią.

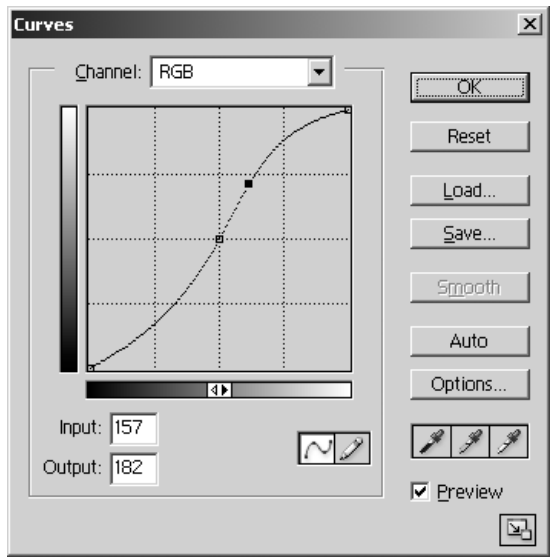

7 pav. Kreivių metodo parametrų langas

Fig 7. Properties of function Curves 
O norint vienu metu tamsias vietas tamsinti, o šviesias šviesinti, reikia kreivę valdyti iškart dviem taškais (sinusoidinis algoritmas).

\section{Skaitmeninio skenuoto vaizdo kokybès vertinimo ir gerinimo algoritmas}

Skaitmeninio žemėlapio vaizdo kokybès vertinimo ir koregavimo veiksmų seka priklauso nuo numatomos skaitmeninio vaizdo paskirties (8 pav.).

Skaitmeninio vaizdo ruošimas toliau vektorizuoti. Jeigu skenuotas vaizdas bus naudojamas vektorizavimui, reikia atkreipti dèmesi $i$ taikomos vektorinès programos ypatumus (pirmiausia - kokius rastrinių duomenų formatus ji turi). Vektorizuojant dažniausiai reikalingas ne visas vaizdas, o tik aiškios kontūrų ribos, todèl galima skenuoti mažesne skyra, pvz. 200 dpi, nes to pakanka, kad matytume smulkias detales, be to, operuoti mažesnio dydžio bylomis yra patogiau ir greičiau. Parinkus tokią skyrą užrašai nuskenuotame žemèlapyje taip pat pakankamai gerai matomi. Jei spalvinè žemèlapio informacija nėra aktuali, galima skenuoti Grayscale režimu, tada skaitmeninio vaizdo apimtis dar labiau sumažeja. Kadangi aukšta vaizdo kokybè nebūtina, siekiant dar labiau sumažinti bylos dydị, skenuotą vaizdą galima išsaugoti suspausto formato (pvz., JPEG, jeigu ši formatą turi naudojama vektorinè programa).

Jei nuskenuotame žemèlapyje vektorizavimui reikalinga informacija (objektų kontūrai, užrašai ir kt.) gerai matoma, vaizdo koregavimo veiksmus galima praleisti. Tačiau vektorizuojant labai svarbu, kad nebūtú geometrinių vaizdo iškraipymų. Todèl reikia imtis veiksmų geometrinėms deformacijoms pašalinti, kartu žemèlapio skaitmeninio pagrindo tikslumui užtikrinti.

Skaitmeninio vaizdo ruošimas spausdinti. Jei skenuotą vaizdą numatome spausdinti, jo kokybė turi būti kiek imanoma geresnè. Kruopščiai parenkame ir paruošiame originalą, kiek imanoma pašalindami defektus. Esant galimybei pasirenkame geresni skeneri ir skenavimo programą. Originalą skenuojame 350 dpi arba dar didesne skyra (didesnès skyros vaizdus geriau koreguoti, tada skyrą galima sumažinti iki reikiamo dydžio). Esant poreikiui ir galimybei, poligrafini muarą pašaliname dar skenuodami. Spalvini režimą parenkame atsižvelgdami i originalo ir spaudos ypatybes. Skenuotą vaizdą išsaugome TIFF formatu.

Kruopščiai įvertiname skenuoto vaizdo kokybę pagal visus parametrus ir imamės reikiamų veiksmų defektams šalinti. Vaizdo kokybę tikriname kiekvienu koregavimo etapu. Jei vaizdo kokybė netinkama, skenuojame iš naujo arba ieškome kito originalo. Ruošiant žemėlapi spausdinti klasikiniu būdu (popieriuje) reikia keisti spalvų modelị iš $R G B$ i $C M Y K$ [8].

Senų žemẻlapių restauravimas ir archyvavimas. Senų žemėlapių restauravimo seka analogiška skaitmeninio vaizdo ruošimui spausdinti, tačiau yra tam tikrų specifinių ypatumų. Pirmiausia, dirbdami su senais žemėlapiais, dažniausiai neturime originalo pasirinkimo galimybès. Jei žemèlapis labai pažeistas, ji reikia skenuoti žymiai didesne (iki 600 dpi) skyra. Kadangi svarbu i skaitmenini vaizdą perkelti originalo spalvas, spalvinị režimą parenkame atsižvelgdami i originalo ypatybes. Didelè tikimybė, kad senas žemèlapis, ypač jeigu jis buvo laikomas prastomis sąlygomis, yra deformuotas, todèl labai svarbu kruopščiai ivertinti ir ištaisyti skenuoto vaizdo geometrines deformacijas. Dažna senǔ žemèlapių problema - skylès. Reikia stengtis kiek imanoma atkurti dingusią informaciją - tam labai praverčia papildomi duomenu šaltiniai (panašūs žemėlapiai). Be to, seni žemèlapiai dažnai esti labai išblukę, todèl būtina atkurti spalvas (9 pav.). Atlikę skenuoto vaizdo koregavimą, skyrą galime sumažinti iki 300-350 dpi.

Skaitmeninio vaizdo dèjimas i internetą. Jeigu skenuotas vaizdas bus dedamas $\mathfrak{i}$ interneta, pakanka skenuoti 75 dpi skyra. Skenuotą vaizdą rekomenduojama saugoti GIF formatu. Šiuo atveju reikalavimai vaizdo kokybei yra mažesni, ištaisome tik akivaizdžius trūkumus.

Skaitmeninio vaizdo naudojimas teminiam žemėlapiui kurti. Rengiant teminius žemėlapius kaip pagrindą galima naudoti skenuotą kito žemèlapio vaizdą. Šiuo atveju skenuoto vaizdo ruošimas labiausiai priklauso nuo teminio žemèlapio paskirties, nes čia svarbesnè informacija, esanti teminiuose sluoksniuose, o ne, pavyzdžiui, naudojamo pagrindo geometrinis tikslumas. Svarbu ištaisyti tik akivaizdžius skaitmeninio vaizdo trūkumus ir, esant poreikiui, pašalinti nereikalingą informaciją.

\section{Išvados}

1. Skenuojant gauto skaitmeninio vaizdo kokybè priklauso nuo skenuojamo originalo kokybès ir skenavimo proceso. Norint gauti poreikius atitinkanti skaitmenini vaizdą, būtina pasirinkti tinkamiausią originalą, skenerị ir skenavimo programą, nustatyti optimalius skenavimo parametrus ir išsaugoti skenuotą vaizdą tinkamu formatu.

2. Autorių nuomone, iš paplitusių grafinių programu skenuotam vaizdui koreguoti geriausiai tinka Adobe PhotoShop programa, kuri leidžia ivertinti ir atitaisyti geometrines deformacijas, pašalinti fizinius pažeidimus, poligrafini muarą, kitus defektus, įvertinti ir koreguoti spalvas.

3. Skaitmeninio vaizdo ruošimo procesas labiausiai priklauso nuo to vaizdo paskirties. Tyrimo metu sudaryta žemėlapio skenavimo ir gauto skaitmeninio vaizdo kokybès vertinimo bei koregavimo metodika leidžia skaitmenini žemèlapi pilnutinai parengti tolesniam naudojimui pagal numatomą paskirti. 


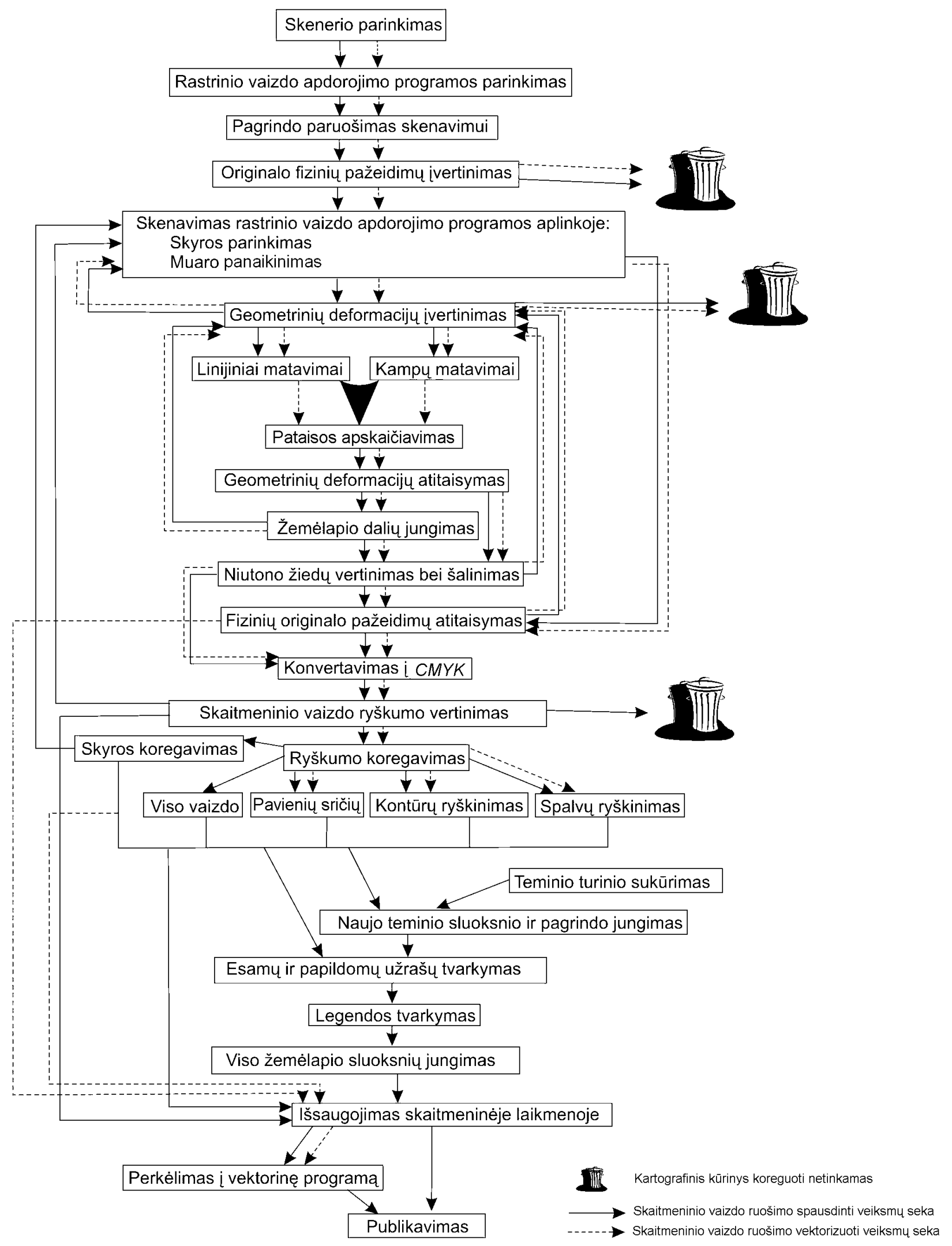

8 pav. Skenuoto žemėlapio vaizdo kokybès vertinimo bei gerinimo algoritmo schema

Fig 8. Methodological sheme of estimating and improving the scanned map quality 


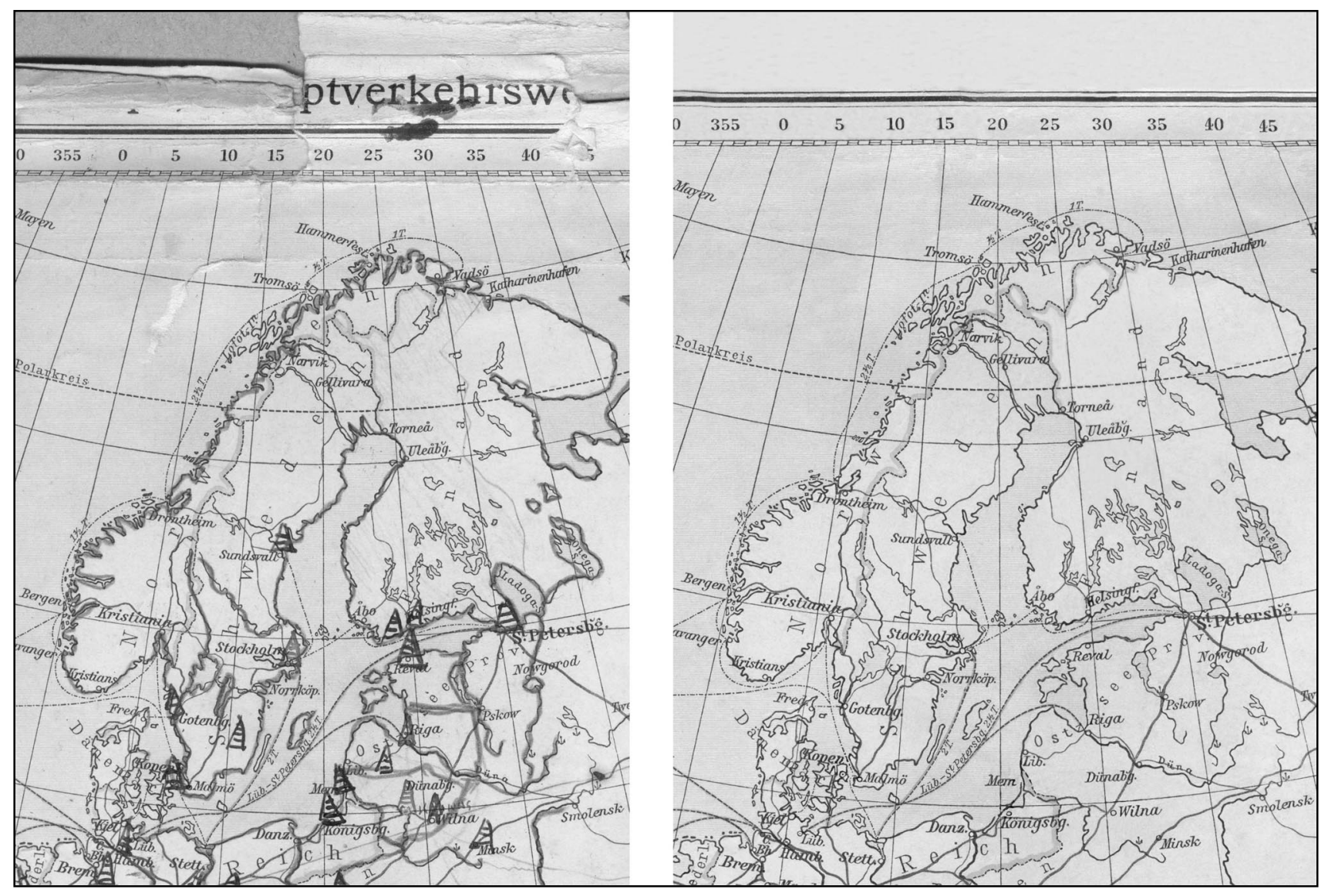

9 pav. Labai pažeisto žemèlapio fragmentas: kairèje - iškart po skenavimo, dešinėje - po atliktų restauravimo darbų Fig 9. Part of old bad quality map: after scanning (left) and after restoration (right)

4. Viena iš svarbiausių skaitmeninio vaizdo koregavimo priemonių grafinèse programose yra filtrai. Ištyrus visus 97 programos Adobe PhotoShop filtrus, nustatyta, kad skaitmeninio žemėlapio vaizdo kokybei gerinti tinka tik trys filtru grupès: Sharpen, Blur ir Noise. Pagal paskirti filtrus galima skirstyti $\mathfrak{i}$ dvi grupes: vaizdo ryškinimo ir suliejimo filtrai. Ryškinimo filtrai leidžia paryškinti ir visą vaizdą (Unsharp Mask), ir pavienes detales - kontūrus, užrašus (Sharpen Edges, Poster Edges). Suliejimo filtrai (Dust\&Scratch, Gaussian Blur, Smart Blur) padeda pašalinti smulkius trukdžius bei poligrafini muarą.

\section{Literatūra}

1. Ponomarenko, S. Adobe PhotoShop 6.0 (Adobe PhotoShop 6), Cbhv. Sankt-Peterburg, 2001 (in Russian).

2. Bautrènas, A. Optimisation of cartographic view in thematic cartography. PhD work, Vilnius University. Vilnius, 2002 (in Lithuanian).

3. Karbo, M. B. Editing of digital views (Skaitmeninių vaizdu apdorojimas). Denmark, 2000 (in Lithuanian).

4. Ginzburg, A.; Milčev, M.; Solonicin, J. Hardware: printers, scanners and digital cameras (Периферийные устройства: принтеры, сканеры, цифровые камеры). Sankt-Peterburg: Piter, 2001 (in Russian).

5. Marej, S. Retouch for beginners (Любительская ретушь), http://www.digitalware.ru/static/dwscanners/DWRscannin g010613-0.asp, 2001 (in Russian).
6. Parilov, A. Adding of graphic data (Ввод графических данных), http://gis.report.ru/material.asp?MID=622, 2002 (in Russian).

7. Burlakov, M. V.; Efects in image-editing programmes (Эффекты в программах растровой графики). Moscow: Binom, 2000 (in Russian).

8. Menšina, E. S. Digital performance of maps for lessons of history (Компьютерная обработка карт для использования на уроках истории), http://center.fio.ru/vio/vio_06/resource/Print/art_1_8.htm, 2002 (in Russian).

9. Milovskij, A. Editing of digital photographs (Обработка изображений в цифровой фотографии), http://www.pmx.ru/index.php3?mod=6\&id_article $=155$, 2002 (in Russian).

Artūras BAUTRÉNAS. Assoc Prof. Vilnius University, M. K. Čiurlionio g. 21/27, LT-03101 Vilnius, Lithuania. (Ph +370 5239 8297, +370 28637495 (mob.), e-mail: arturas.bautrenas@gf.vu.lt.

Jana KONSTANTINOVA. Assistant. Institute of Geology and Geography, T. Ševčenkos g. 13, LT-03223 Vilnius, Lithuania. ( $\mathrm{Ph}+3705$ 2104709, 868638644 (mob.), Fax: +370 5 2104695), e-mail: jana@geo.lt.

\footnotetext{
Marijus PILECKAS. Doctoral student. Institute of Geology and Geography, T. Ševčenkos g. 13, LT-03223 Vilnius,

Lithuania.

(Ph +370 5 2104709, 868782327 (mob), Fax: +370 5 2104695),

e-mail: marijus@geo.lt.
} 